\begin{tabular}{l}
\hline 統 \\
\hline
\end{tabular}

\title{
薬疹の統計的ならびに臨床的観察
}

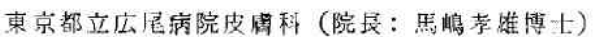 \\ 関滕成文
}

\section{Statistical and Clinical Observation of Drug Eruption}

\author{
Naribumi SEKIDO \\ Division of Dermatology, Tokyo Metropolitan Hospital Hiro-o \\ Tokyo, Japan (Director: Dr. T. Majima)
}

The patients of drug eruptions who attended the Department of Dermatology, Branch Hospital, University of Tokyo, from 1966 to 1968 , were 113 persons or $1.08 \%$ of the total outpatients. The number of drug eruption patients in their twenties was the largest-31 persons, and those in their thirties was the next largest-28 persons. The sum of both groups was slightly more than half of the total drug eruption patients.

Cutaneous eruptions were classified according to the list of American Medical Association. Fixed eruption with $45.1 \%$ was the largest, followed by exanthematic eruption with $25.7 \%$. erythematous eruptions with $11.5 \%$, papulovesicular eruption with $8 \%$, urticarial eruption with $2.7 \%$, erythroderma with $0.9 \%$, acne form with $09 \%$, toxic epidermal necrolysis with $0.9 \%$, photosensitive eruption with $0.9 \%$.

Causative drugs of 10 cases were ascertained by a provocation test and the ones of another 21 cases were suspected by determing that the patient had used one drug only. The largest group of causative drugs was antibiotics with 12 cases, followed by sulfonamide with 8 cases, sedativa with 2 cases and so on. Of the drugs used, chloramphenicol in 5 cases, sulfisomezole in 3 cases and carbamazepine in 2 cases were outstanding.

Both in exanthematic and in papulovesicular eruptions, trunk and extremities were frequently involved but the face was seidom affected. In erythematous eruption, extremities most were frequently involved; secondarily, the face and trunk were affected.

The dosage of drug, used in the provocation tests of exanthematic, papulovesicular and erythematous eruptions, was about one fifth of the normal single dose and when no reactions were observed in the following 24 hours, an additional dosage was used.

If the distribution of exanthems in the provocation test was compared with that in the previous reaction, areas which were at an early stage and severely involved were unchanged. The tendency was observed that exanthems appeared earlier in the arms than legs.

In 3 of 6 provocation tests, leukocytosis was observed. In other 3 , leukopenia was observed. A decrease in the number of platelet was observed in both cases.

\section{はじめに}

昭和 41 年から 43 年まで 3 年間の東京大学分院皮虚科 における蒋疹患者を統計的ならびに臨床的汇観察し，特 に皮疹分布について考察を行なつた。また，内服試験を 行なつた症例については, その方法, 誘発後の皮落の動 き, 白临球数の変動などを倹討した。

\section{I. 統計的観察，特に疮型を中心に}

3 年間の皮有科外来患者総数は 10499 名で，そのう 古，薬疹患者は 113 例 $(1.08 \%$ ) を数えた。年度別では 昭和 41 年 30 例， 42 年 49 例，43 年 34 例で，それぞれ 外来患者総数の $0.8 \% ， 1.4 \% ， 1.05 \%$ であった(第। 表)。

㾉型別には（第１表），固定疹型加もつをも多く51 例 
第 1 表 疹型の頻度と対外来患者比

\begin{tabular}{|c|c|c|c|c|c|c|}
\hline 疹型 作 & 炤41 & 昭42 & 炤43 & 計 & 男 & 女 \\
\hline 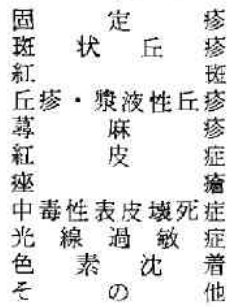 & $\begin{array}{r}14 \\
6 \\
3 \\
2 \\
2 \\
1 \\
0 \\
1 \\
0 \\
0 \\
1\end{array}$ & $\begin{array}{r}19 \\
15 \\
7 \\
4 \\
1 \\
0 \\
1 \\
0 \\
1 \\
0 \\
1\end{array}$ & $\begin{array}{r}18 \\
8 \\
3 \\
3 \\
0 \\
0 \\
0 \\
0 \\
0 \\
1 \\
1\end{array}$ & $\begin{array}{r}51 \\
29 \\
13 \\
9 \\
3 \\
1 \\
1 \\
1 \\
1 \\
1 \\
3\end{array}$ & $\begin{array}{r}27 \\
9 \\
6 \\
5 \\
2 \\
0 \\
0 \\
1 \\
0 \\
0 \\
1\end{array}$ & $\begin{array}{r}24 \\
20 \\
7 \\
4 \\
1 \\
1 \\
1 \\
0 \\
1 \\
1 \\
2\end{array}$ \\
\hline 計 & 30 & 49 & 34 & 113 & 51 & 62 \\
\hline
\end{tabular}

外来患者䋓数 $3,7653,4913,243 \quad 10,499$

\begin{tabular}{l|l|l|l|l|l} 
対外来患者比 $(\%)$ & 0.80 & 1.40 & 1.05 & 1.08
\end{tabular}
第 2 表 荟型上年令との関係

\begin{tabular}{|c|c|c|c|c|c|c|c|c|c|}
\hline 疹型 & $\begin{array}{l}0 \\
? \\
9\end{array}$ & $\begin{array}{l}10 \\
19\end{array}$ & $\begin{array}{c}20 \\
2 \\
29\end{array}$ & $\begin{array}{l}30 \\
? \\
39 \\
\end{array}$ & $\begin{array}{l}40 \\
? \\
49\end{array}$ & $\begin{array}{l}50 \\
? \\
59\end{array}$ & $\begin{array}{c}60 \\
\zeta \\
69\end{array}$ & $\begin{array}{c}70 \\
? \\
79 \\
\end{array}$ & \\
\hline 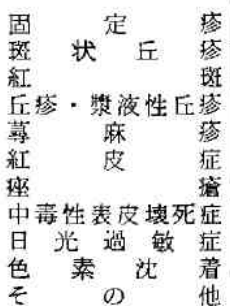 & $\begin{array}{l}3 \\
1 \\
1 \\
0 \\
0 \\
0 \\
0 \\
0 \\
0 \\
0 \\
0\end{array}$ & $\begin{array}{l}8 \\
4 \\
0 \\
2 \\
0 \\
0 \\
0 \\
0 \\
0 \\
0 \\
0\end{array}$ & $\begin{array}{r}12 \\
9 \\
4 \\
3 \\
1 \\
1 \\
0 \\
0 \\
0 \\
0 \\
1\end{array}$ & $\begin{array}{r}12 \\
7 \\
5 \\
0 \\
1 \\
0 \\
1 \\
0 \\
1 \\
1 \\
0\end{array}$ & $\begin{array}{l}9 \\
3 \\
1 \\
0 \\
0 \\
0 \\
0 \\
0 \\
0 \\
0 \\
1\end{array}$ & $\begin{array}{l}4 \\
2 \\
0 \\
3 \\
0 \\
0 \\
0 \\
0 \\
0 \\
0 \\
1\end{array}$ & $\begin{array}{l}1 \\
3 \\
2 \\
1 \\
1 \\
0 \\
0 \\
1 \\
0 \\
0 \\
0\end{array}$ & $\begin{array}{l}2 \\
0 \\
0 \\
0 \\
0 \\
0 \\
0 \\
0 \\
0 \\
0 \\
0\end{array}$ & $\begin{array}{l}0 \\
0 \\
0 \\
0 \\
0 \\
0 \\
0 \\
0 \\
0 \\
0 \\
0\end{array}$ \\
\hline 計 & 5 & 14 & 31 & 28 & 14 & 10 & 9 & 2 & 0 \\
\hline & $\begin{array}{l}5 \\
0\end{array}$ & $\begin{array}{l}9 \\
5\end{array}$ & $\begin{array}{l}12 \\
19\end{array}$ & $\begin{array}{l}12 \\
16\end{array}$ & $\begin{array}{l}5 \\
9\end{array}$ & $\begin{array}{l}2 \\
8\end{array}$ & $\begin{array}{l}4 \\
5\end{array}$ & $\begin{array}{l}2 \\
0\end{array}$ & $\begin{array}{l}0 \\
0\end{array}$ \\
\hline
\end{tabular}

第 3 表原团薬と疹型の関係

\begin{tabular}{|c|c|c|c|c|c|c|c|c|c|c|c|c|}
\hline 原 内葲疼型 & 固定疮 & $\begin{array}{l}\text { 斑状 } \\
\text { 丘疹 }\end{array}$ & 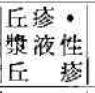 & 紅非 & 荡麻疮 & 紅皮症 & 侳瘖 & $\mid \begin{array}{l}\text { 中㶳性 } \\
\text { 表皮 } \\
\text { 壊死症 }\end{array}$ & $\mid \begin{array}{ll}\text { 日 } & \text { 光 } \\
\text { 過敏 晸 }\end{array}$ & $\begin{array}{l}\text { 绝素 } \\
\text { 疒着 }\end{array}$ & その他 & 合計 \\
\hline 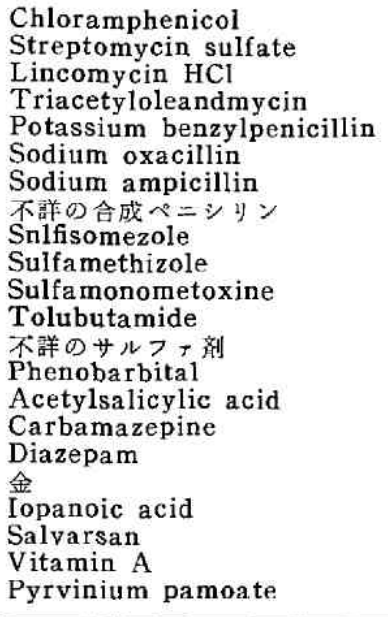 & $1^{*}$ & $\begin{array}{l}4 \\
1^{* *} \\
1^{* *} \\
\\
1 \\
1 * \\
1 \\
1\end{array}$ & $1^{*}$ & $\begin{array}{c}1 \\
1 \\
1^{*}, 1 \\
1 \\
1 \\
1\end{array}$ & 1 & $1^{*}$ & & $1^{*}$ & ! & 1 & 1 & $\begin{array}{l}5 \\
1 \\
1 \\
1 \\
1 \\
1 \\
1 \\
1 \\
3 \\
1 \\
2 \\
1 \\
1 \\
1 \\
1 \\
2 \\
1 \\
2 \\
1 \\
1 \\
1 \\
1\end{array}$ \\
\hline 計 & 1 & 12 & 3 & 7 & 3 & 1 & 0 & 1 & 1 & 1 & 1 & 31 \\
\hline
\end{tabular}

(45.1\%), 次いで斑状丘疹型 29 例 $(25.7 \%)$, 紅斑型 13 例 $(11.5 \%)$, 丘疹・漿液性斥疹型 9 例 $(8 \%)$, 薄 麻疮型 3 例 (2.7\%) で，紅皮症型，痤㾑型，中毒性表 皮壊死症型, 光線過敏症型, 任素沈着型がそれぞれ 1 例 (0.9\%) で, 分類不能のもの加3例あつた（後述）。

（1）疹型之年令・性別上の関係（第1，2表）

年令別では, 薬疹全体では 20 才代がもつとむ多く 31 例，30才代 28 例がこれに次ざ両者をあわすと全薬疹例 の52\%を占め，これらをピークとしてより若年および老
年に问つて渐減していた。

疹型別では固定疹型, 斑状丘疹型, 新斑型は20才代, 30 才代に多く，乙れら各疼型はこの両年代では約半数 を占め，上り若年及び老年に向つて潄減し，他方，丘疹 ・漿液性丘型では30才代，40才代では㫮無で，20才 代上 50 才代にもつ上あ多く2 峰性を示した。

性別では男 51 例，女 62 例で，斑状丘疹型で女子が特 に多く, 固定疼型, 丘疹・獎液性丘疹型, 惹麻疹型でわ ずかに男子が多く（第 1 表），年令別では70才代と10才 
第 4 表 斑状开疹型の皮疹分布

\begin{tabular}{|c|c|c|c|c|c|}
\hline \multicolumn{2}{|c|}{ 疹分布年 皮 } & 绍 41 & 昭 42 & 略 43 & 訫 \\
\hline $\begin{array}{c}1 \text { 区分 } \\
\text { 数 }\end{array}$ & 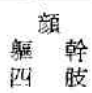 & $\begin{array}{l}0 \\
1 \\
2\end{array}$ & $\begin{array}{l}1 \\
3 \\
1\end{array}$ & $\begin{array}{l}0 \\
1 \\
0\end{array}$ & $\begin{array}{l}1 \\
5 \\
3^{* *}\end{array}$ \\
\hline \multicolumn{2}{|c|}{2 区分にわたる例数 } & 1 & 4 & 2 & 7 \\
\hline \multicolumn{2}{|c|}{ 3区分比わたる例数 } & 2 & 6 & 5 & 13 \\
\hline 部 & & 6 & 15 & 8 & 29 \\
\hline
\end{tabular}

*) 3 例上娄上肢と下肢飞皮疹があつた。

第 5 表 2 区分にわたる斑状近疹型皮应分布

\begin{tabular}{|c|c|c|c|c|}
\hline 皮抮分布 & 明 41 & 昭 42 & 띵 43 & 詮 \\
\hline 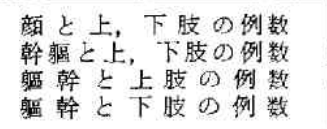 & $\begin{array}{l}1 \\
0 \\
0 \\
0\end{array}$ & $\begin{array}{l}0 \\
2 \\
1 \\
1\end{array}$ & $\begin{array}{l}0 \\
1 \\
0 \\
1\end{array}$ & $\begin{array}{l}1 \\
1 \\
2 \\
3\end{array}$ \\
\hline$F 1$ & 1 & 4 & 2 & 7 \\
\hline
\end{tabular}

代以下を除いて女子が多数を占めた（第 2 表）。

（2）疹型之原因蒋との関係（第 3 表）

113 例中，原因薬が確認または推定できたるのは 31 例で，その内容は，内服または注射により確認できた 6の 8 例 (内服 7 例，注射 1 例)，貼布試験に上り確認 できたもの 2 例，使用薬が 1 種のため，それを原因薬と 推定したもの 21 例であつた。

この31例では chloramphenicol がもつとも多く 5 例, sulfisomezole が 3 例, sulfamonometoxine, carbamazepine, 金が各 2 例, その他が各 1 例であつ た。

疹型的には玟状丘疹型 12 例, 紅斑型 7 例， E-疹・獎 液性丘疹型 3 例, 薄麻疹型 3 例, 紅皮症型, 中毒性表皮 壊死症型，色素沈着型が各 1 例で, chloramphenicol

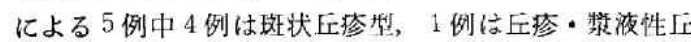
疹型であつた。

\section{II. 統計的観察, 特に各疹型の皮疮 分布之原因薬との関係}

全身を(1)䫓を含めた顔，(2)頸，項部を含めた軀幹，(3) 四肢の 3 区分とし，さらに(4)乙れらの内の 2 区分にわた つたもの，(5) 3 区分にわたつたものの5群沉わけ，各疹 型につき皮疹分布之原因祭之の関係を検討した。

(1) 斑状丘答について：との将型は 29 例にみられ 皮疹が 1 区分に限られたすの 9 例，2区分にわたつたす の 7 例，3区分にわたつたもの13 例であつた(第 4 表)。
第6表 3 区分にわたる斑状丘疹型の皮症分倣

\begin{tabular}{|c|c|c|c|c|}
\hline 皮荟分布 & 绦41 & 炤42 & 吸43 & rit \\
\hline $\begin{array}{l}\text { 顔と躯幹と上, 下肢の例数 } \\
\text { 顔と㺿幹上上肢の例数 }\end{array}$ & 1 & $\begin{array}{l}7 \\
0\end{array}$ & $\begin{array}{l}3 \\
1\end{array}$ & $\begin{array}{r}11 \\
2\end{array}$ \\
\hline 15 & 2 & 7 & 4 & 13 \\
\hline
\end{tabular}

第 7 表 丘痊・將波性丘疹型の皮㻅分有

\begin{tabular}{|c|c|c|c|c|c|}
\hline 皮症分布 年 & $\lim 41$ & Biz $\{42$ & IR 43 & 計 & 倫 \\
\hline 1 区分の例数 & 1 & 2 & 0 & 3 & すへて上，下肢 \\
\hline 2 区分にわたる例数 & 0 & 2 & 0 & 2 & 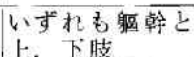 \\
\hline 3 区ふにわたる例数 & 1 & 0 & 3 & 4 & 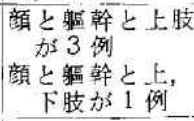 \\
\hline 計 & 2 & 4 & 3 & 9 & \\
\hline
\end{tabular}

1 区分に限られたものは㺿幹 5 例, 四肢 3 例, 顔 1 例 で，2区分にわたつたものは(第 5 表)，四肢と軀幹が 6 例, 四肢之顔が 1 例であつた。つまりとれらの所見か らすると, 皮疹は大多数では挋幹, 四肢に見われ, 顔に は少ないことがわかる。さらに3区分にわたつたあので は (第 6 表), 全 13 例が顔, 躬幹, 上肢に, 内 11 例飞 は下肢にあ皮祅がみられた。

他方，乙の疹型 29 例中，原因薬の確認できたものは， 内服または注射による2 例, 貼布試験による2 例，1種 類の使用薬剤による 8 例の計 12 例で，その内訳はサル ファ剂による四肢つみが 1 例, chloramphenicol また は金剂による躯幹のみがそれぞれ 1 例，合成ペニシリン による顔のみが 1 例，さらに金剂に上る四肢之躲幹の 2 区分にわたつたもの1例，また sulfisomezole， streptomycin sulfate, lincomycin $\mathrm{HCl}$ による各1例およ び chloramphenicol による3例はすべて3区分にわた つてみられた。とのように原因薬と皮疹分布の間に一定 の関係は見出しえなかつたが，ただ chloramphenicol の4例ではすべて舸幹にみられたことがやや注目され た。

（2）近疹・墏液性丘疹型について：この疹型は 9 例に みられ，皮疹が 1 区分に限ら机たもの 3 例，2区分にわ たつたむの 2例，3区分にわたつたもの4例であった (第 7 表)。1 区分に限られたものはすべて四肢に，2区 分にわたつたあのはす心゙て四肢し凮幹であつた。すふわ ちこの型型は四肢，ついで蟠幹に現われ，顔には現われ ていないととがわ加る。さらに3区分にわたつた 4 例

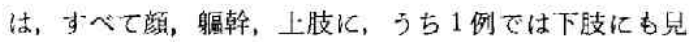


第 8 表紅斑型の分数と原团楽（2剂またのもの）

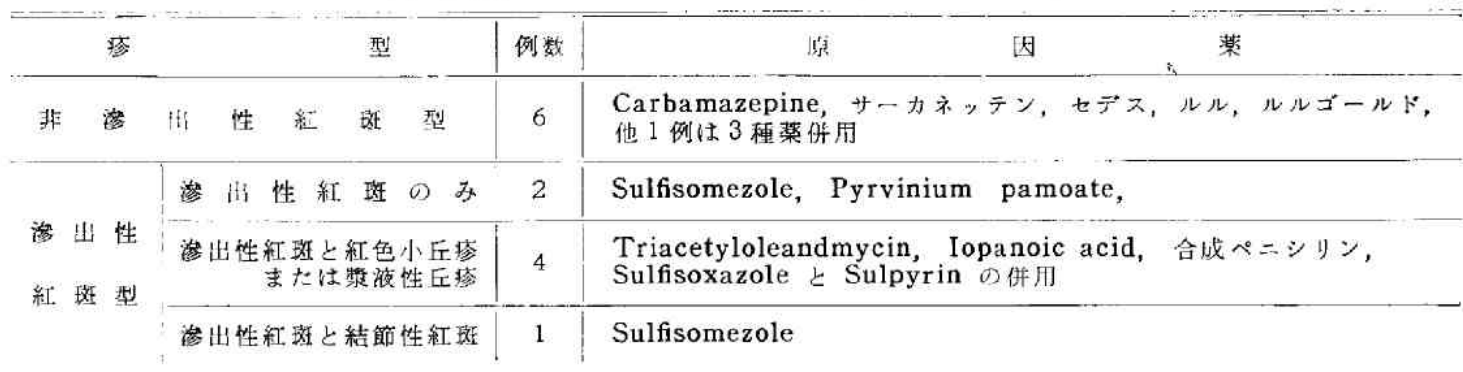

第 9 表 組斑型 0 皮落你布

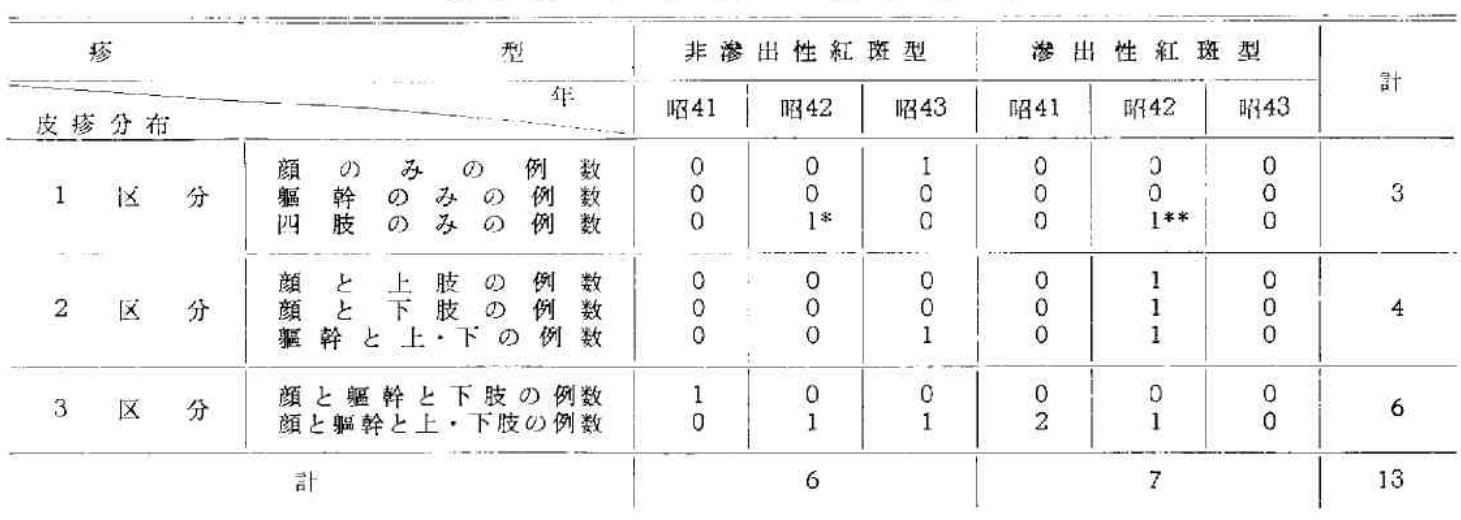

*：上肢と下肢を侵す **：上肢のみを琂す

られた。

この疹型９例中，原因薬の確認できたものは 3 例で (内服に上るむの 2 例， 1 種類の使用菜に上るらの 1 例), その内䚿は sodium oxacillin による全身性のも の1例, chloramphenicol または phenobarbital に よる阳肢のみが各 1 例で，とこです原因薬と皮疮分有上 の間に一定の関係は見出せなかつた。

(3) 紅斑型について：この疹型は 13 例みられ，この うち，7例は滲出性紅斑型，残り6例は非洷出性紅斑型 であつた。淩出性紅斑型では，純粋の渗出性紅斑が 2 洌，泫出性紅斑のほかに紅色小丘疹，小紅斑，漿液性丘 疹，結節性紅斑などの混在するもの 5 例であつた（第 8 表)。

この泠型は1区分に煺られたあの3例，2区分にわた つたもの4例，3区分にわたつたすの6例であつた（第 9 表)。1 区分に限られた 3 例は顔 1 例，四肢 2 例で， また 2 区分にわたつた 4 例は顔之四肢 2 例，軀幹亡四肢 2 例で，四肢にすつ上6現われやすく，顔と颐幹がこれ についでいた。さらに3区分にわたつた6例では上肢に みられないるのは1例しかなかつた。

この侩型 13 例中，原因桼の碓認できたものは6例で
(すへて 1 種類の使用薬から推定), その内訳は sulfisomezole 2 例, carbamazepine, triacetyloleandmycin, iopanoic acid, pyruvinium pamoate 各 1 例 で, sulfisomezole の1例は顔, iopanoic acid による むのは顔と上肢, 残りの 4 例は全身に皮疹がみられ，こ こでも原因薬と皮疹分布との間に，一定の関係は見出+ なかつた。

（4）他の疹型について（第 1，3表）：摰麻贸は pen-

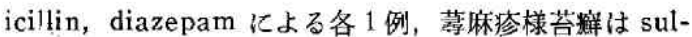
famethizole による 1 例，紅皮症は carbamazepineの 1 例, 座㾑は calcium aminosalicylate $と$ isoniazidium 在併用せる 1 例，光線過敏症はビタミンA（筋注） の1例，色素堵着は tolubutamide により胸北に絧状 色素沈着をみた1例があつた。

固定疹は 51 例みられ，その原因薬は，内服試験に よる sulfamonometoxine 1例, 問診加ら推定したむ のが「グレラン」,「ルル」,「セデス」,「ノーシン」, pyrabital, amobarbital, sulfisomezole, sulfamonometoxine, sulfadimetoxine などであつた。

丧中の「その他」の3例は salvarsan による発疹後

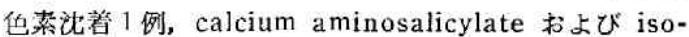


niazidium の併用内服による 四肢露出部の出血性㢡液 性丘疹 1 例, potassium benzylpenicillin 筋注( 3 日) 部位の浮腫性浸润性紅斑之集簇性紅色小丘疹の 1 例であ つた。

\section{III. 内服試験により原因薬を 確認しえた症例の検討}

7 例中, 固定疹 1 例を除き 6 例につき記述する。

第1例 27 才，女子。 Sulfisomezole に上る 玟状丘 型。

既往歴：4才腎炎，19才低血圧。

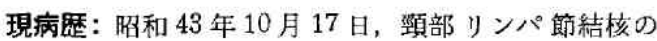
診断で isoniazidium, sulfisomezole を 1 回内服後， 発熱があり，その後あ内服どさに発熱したが，10日間内 服し，全身の発赫のた服用中止した。Prednisolone $30 \mathrm{mg} /$ 日 で解熱し，10月 31 日東大分院を受䛦した。

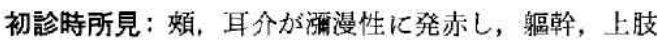
に爪甲大までの紅斑が播種性に存在し一部は融合してい る。下肢には紅色小丘疹が播種性に存在し，掌踣に小丘 疹が多発し, 癌释がある。

経過およひ誘発試験：Prednisolone $30 \mathrm{mg} /$ 日より 辢娍して6 日間内服し, 皮疹は消失した。(1)貼布試駿; $20 \%$ sodium sulfisomezole 親水軟高を貼布したとこ ろ， 24 時間後に浮腫性 紅斑が出現し，貼布を除去した 翌日には落居性淡褐色斑となつた。Streptomycin sulfate 粉末抄よび20\% sulphyrin vaselin 貼布はいずれ あ隃性であつた。(2)内服試験; Sulfisomezole $0.25 \mathrm{~g}$ を内服させたが， 1 時問後反応がないので $0.25 \mathrm{~g}$ を追 加した。との時点を内服武験開始点とすると，30 分後 に咽頭荤和感， 2 時間後に咳嗽発作，煩，耳介，胸， 腹, 上肢色素斑の発赤, 頭演, 全身遑和感が出現した が，発熱はなかつた。ただちに dexamethasone sodium phosphate $4 \mathrm{mg}$ の筋注とブドウ糖の点滴を行 なつた。その 5 時間後になお $39^{\circ} \mathrm{C}$ の発熱と悪寒がみら れ，血圧が $98 / 60$ であつたため dexamethasone を 追加し, 以後诀方飞向った。

以上，本例は sulfisomezole に上る斑状丘将型で， 内服により煩，耳介に濑漫性の発赤，上肢に小紅斑，つ いで胸，腹にも小紅斑が多発し，白血球減少があり，貼 布試験が陽性で, 発疹前に drug fever のみが 7 日間 続き，血清 LDH が高値を示した。

第2 例 29 才，女子。Sodium oxacillin に上る丘涔 . 烦液性丘疹型。

既往歴：23才腎衁炎。
第 10 表 第 2 例の穿剌試験 (25分後の胿疹/紅斑の直径, 単位 $\mathrm{mm}$ )

\begin{tabular}{l|c|c}
\hline & $\begin{array}{c}596 \text { Sodium } \\
\text { oxacillin 生食液 }\end{array}$ & 生 食 波 \\
\hline 患 者 & $3 \times 5 / 3 \times 5$ & $0 \times 0 / 1.5 \times 1.5$ \\
刘然正常人 & $1 \times 1 / 1 \times 1$ & $0 \times 0 / 1.5 \times 1.5$
\end{tabular}

第 11 表 第 2 例の皮内反莣

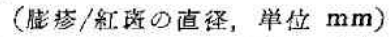

\begin{tabular}{|c|c|c|c|}
\hline & & $\begin{array}{l}5 \% \text { Sodium } \\
\text { oxacillin 生含液 }\end{array}$ & 生 食 液 \\
\hline 者 & $\begin{array}{l}15 \text { 分 } \\
30 \text { 分 } \\
4 \text { 应間 }\end{array}$ & $\begin{array}{r}7 \times 8 / 11 \times 12 \\
11 \times 10 / 12 \times 13 \\
6 \times 6 / 10 \times 8\end{array}$ & $\begin{array}{l}0 \times 0 / 0 \times 0 \\
0 \times 0 / 0 \times 0 \\
0 \times 0 / 0 \times 0\end{array}$ \\
\hline 対照正常人 & $\begin{array}{l}15 \text { 分 } \\
30 \text { 分 } \\
4 \text { 琼間 }\end{array}$ & $\begin{array}{l}7 \times 7 / 7 \times 7 \\
7 \times 7 / 14 \times 13 \\
5 \times 2 / 0 \times 0\end{array}$ & $\begin{array}{l}7 \times 7 / 7 \times 7 \\
6 \times 6 / 7 \times 7 \\
0 \times 0 / 2 \times 2\end{array}$ \\
\hline
\end{tabular}

現病歴：昭和 43 年 7 月, rheumatoid arthritis の 骖断で sodium oxacillin 28 日間内服し, $39^{\circ} \mathrm{C}$ の発 熱, 頝部の発赤, 患心, 嘔吐が出現したが, さらに8日 間内服し，全身に皮疹が应大したため，8月15日，果大 分院を受診した。

初晾時所見：全身に采粒大の紅色丘疹，漿液性丘疹， 小紅斑が播種性に存在し融合している。煩には浮腫性紅 斑がみとめられ，指趾先端と足蹀外縁のみに正常皮層汃 残存している。

経過および誘発試験：Dexamethasone $30 \mathrm{mg} /$ 日よ り渐減し 7 日間内服, 皮疹はほぼ消失した。その 1 週 間後に誘発試験を施行した。(1)貼布試験；10\% sodium oxacillin vaselin の㙋布試験は陰性であつた。(2)穿刺

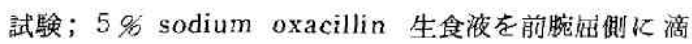
下, 穿刺し, 5 分後に拭き， 25 分後に膨疹/紅斑の直径 を測定したところ陰性であつた（第 10 表）。しかし，穿 刺した前腕には 24 時間後までしびれ感があった。(2)皮 内反応 (第 1 回); Potassium benzylpenicillin 2000 単位を生食 $1 \mathrm{ml}$ 亿溶かし， $0.05 \mathrm{ml}$ を前腕届側皮内に 注射, 15 分後の膨奖/紅斑の淔径を計測したが, 正常人 上差異はなかつた。(4)皮内反応（第 2 回); 5 名 sodium oxacillin 生食液 $0.05 \mathrm{ml}$ 前腕屈側皮內に注射， 15 分後, 30 分後, 4 時間後に測定し， 1 時間後の紅榇 に正常人之の有意差を認めた（第 11 表）。(5)内服試䮖； Sodium oxacillin $250 \mathrm{mg}$ を内服させたが，6時間後， 反心功ないため $250 \mathrm{mg}$ を追加内服させた。。ひ時点 を内服試験開始点上する之， 3 時閒後に前腕に瘙㾕感，

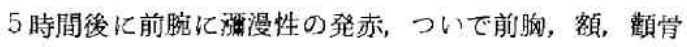
部に爪甲人までの多数の紅斑が出現し， $38^{\circ} \mathrm{C} の$ 発熱が みられた。Prednisolone の内服, dexamethasone の 
筇注により解熱し，皮疹は消退に向つた。24時間後 には不快感はのてつていたすのの皮疹は完全に消失し た。

以上, 本例は sodium oxacillin 飞よる氒落・嶈液 性丘疹型で, 内服により上肢, 次いで胸部, 顔面に紅斑 が現われ, 白血球增多 $(10700 / \mathrm{cmm})$, 特飞多核白血球 増加 $(7.9 \%)$ が顕著で, 栓球減少 $\left(5 \times 10^{4} / \mathrm{cmm}\right)$ 加 あり, 皮内反応は 4 時間後飞対照正常人上有意差があつ た。

第3 例 55 才，女子。 Phenobarbital による丘疹・

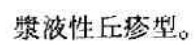

現病歴およひ現症：心蛓神経症のためBellergal 3 鉈 /日を 4 日間内服後, 手背, 前腕, 足背, 下腿に対称性 に, 疼序性小丘疹が現われ, さらに2 日間内服後, 紅色 小丘疹は增加し墏腹性小丘落が混在し, $39^{\circ} \mathrm{C}$ の発熱も みとめられた。顔面、躽幹には皮疹はみられなかつた。 昭和 41 年 6 月 26 日, 東大分院索受㟝した。

経過および誘発試験：Bellergal 中止と副腎皮犋ホル モン内服によつて皮疹は急速に消退した。その 2 週間後 飞 phenobarbital $20 \mathrm{mg}$ を内服させたが 30 時間後ま で反応がないため $100 \mathrm{mg}$ を追加して内服させた。をの 14 時間後, 左右前脆出側飞, 半米粒大の丘疹が現われ, 翌日には前腕伸側にも現われた。

以上，本例は phenobarbital に上る丘稜・漿波性丘 疹型で, 内服により皮疹は前腕, ついで手, 下腿, 足に 波及し, 白血球数の変動はみられなかった。

第4例 67 才，女子。Sulfisomezole Kよる紅斑型 (多形嚐出性紅斑ならびに結節性紅斑型)。

現病歴: 外傷のため penicillin 筇注, sulfisomezole $2 \mathrm{~g} /$ 日を 2 日問内服, 翌日より顔に小膿施が集簇し，四 肢に桜実大, 指頭大の紅斑汃散在性に出現, $39^{\circ} \mathrm{C}$ の発 熟と悪感戦慓加あつた。昭和 41 年 9 月 24 日, 東大分院 を受晾した。

初諺時所見：眼井，煩，鼻下部に対称性，境界明確な 発赤腫脹面があり，その上に小膿疮が密生し，腹部，前 腕，手背に小豆大，爪甲大，紫紅色，渗出性の紅斑が散 在し，ところにより血椸形成上浸潤があり，下肢に結節 性紅斑様皮奖が, 散在する。膿疮ならびに静脈血の細菌 培羪は陰性であつた。

経過およひ燯発試験：Chloramphenicol $1 \mathrm{~g} /$ 日，3 日, prednisolone $30 \mathrm{mg} /$ 日 から濑減して 8 日内服 し, 皮疹は消退した。その 1 週間後に誘発武騃を施行し た。(1)貼们試験；10\%，20\% sodium sulfisomezole vaselin の䀡布試験は陰性であった。(2)内服試験；Su1- fisomezole $0.2 \mathrm{~g}$ を内服させた.5 24 時閭後に反応がな いため $0.5 \mathrm{~g}$ を追加して内服させた。その 1 時間後, $37.5^{\circ} \mathrm{C}$ の発熱と指背, 于背に小紅斑, 多形渗出性 紅斑 が散在性に出現した。Dexamethasone を筋注, 点滴 し, 6 時間後に解熱し，しびれ感も消退, 翌日には皮疹 あ消退した。

以上, 本例は sulfisomezole による紅斑型で, 顔面 に紅斑, 上肢, 腹部に多形淩出性紅斑, 下肢に結節性紅 斑があり，特異なすのは顔面紅斑上に無菌性膿泡が集簇 乙, 白血球增多 $(18200 / \mathrm{cmm})$, 特に多核白血球增加 (84\%) が著しく，尿汇白血球・赤血球が多数みられ, 血清尿菜窒素が増加していたととである。

第5 例 29 才，女子。Carbamazepine による紅皮 症型。

現病歷：頻诵のため昭和 41 年 8 月ころからときおり carbamazepine を内服し，そのたびに $39^{\circ} \mathrm{C}$ の発熱と 麻疹粎の皮疹が出現していた。今回む前日に内服した後 8 月 19 日, 東大分院を受診した。

初診時所見：掌蹠を除く全身に浸潤性・涀漫性発赤が あり，加えて囅幹に爪甲大の褐色斑が散在し，下肢には 料接様洛屑がみられる。下腿, 足は浮腫状に腫脹してい る。

経過および誘発試験：Prednisolone $30 \mathrm{mg} /$ 日加ら 渐隇, 8 日間内服し, 皮疹はほ活消退した。その2 日後 carbamazepine $200 \mathrm{mg}$ を内服させたところ，2 分後

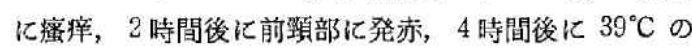
発熱と全身の発赤, 手足の浮腫が出現した。10\% carbamazepine vaseline の貼布陚験は陰性であつた。

以上, 本例は carbamazepine に上る紅皮庭型で, 掌 既以外の 全身が侵され，内服により皮翏は頸部に始ま $\eta$, 急速に全身江拡大し, 白血球增多 $(12200 / \mathrm{cmm})$, 特に好酸球增加 (45\%) が著明であつた。

第6 例 60 才，男子。Sulfamonometoxine Kよる 中毒性表皮壊死症型。

既往歴：2 年前より顔に円盤状紅玟性狼㾑。

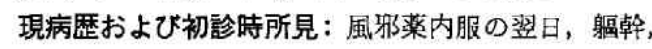
四肢に指頭大の紅褐色竝が多発し，表面は 細㿮億に富 み，乙すると表皮が剝離し，硝子圧で祸色調を残す。

経過および誘発試験：Dexamethasone $1.5 \mathrm{mg} /$ 日 加ら渐減し 7 日問内服し, 皮疹出消退した。その 3 日 後, sulfamonometoxine $500 \mathrm{mg}$ を内服し, 30 分後 に胸部に小紅斑が散発した。ただちに prednisolone $20 \mathrm{mg} /$ 日を队服させたとてろ解熱したが，翌日顔面， 
軀幹，指趾関節背面に指頭大の紅斑が出現した。これら 紅斑は前回発症部位之必ずしも一玫しない。10\% sulfamonometoxine vaselin の貼布武験は陰性であつ た。

以上，本例は sulfamonometoxine による中畵性表 皮壊死症型で，指頭大の紅褐色斑が四肢，軀幹に現わ れ，摩摖により表皮副離をおこした。内服時に白血球減 少 $(3520 / \mathrm{cmm})$ があるが，紅流性狼猃との関係をあわ せ考える必要がある。

\section{IV. 考按}

1. 頻度に関連して 皮觕疾患全体にたいする頻度を 同年代の記録亡くらべると，樋口ら (九大) ${ }^{1)}$ は昭和 29 $\sim 40$ 年に年間 $9 \sim 38$ 例 $(0.18 \sim 0.78 \%) ， 10$ 年飞 38 例 $(0.78 \%)$ ，溝口 (専売東京病院) 21 は同 29 40 年に年間 $8 \sim 41$ 例 $(0.74 \sim 2.02 \%) ， 40$ 年飞 35 例 $(1.74 \%)$, 安 田ら (関東遁信病院) ${ }^{3)}$ は同 $30 \sim 42$ 年に年間 $23 \sim 89$ 例 $(0.35 \sim 1.03 \%), 41$ 年飞 89 例 $(1.03 \%) ， 42$ 年に 64 例 $(0.85 \%)$, 小鳴ら 4 は同 40 年度の東京地域 の啁查で 1881 例 (1.1\%), 白井ら (奈良医大) ${ }^{5)}$ は同 40 42 年に 年間 26 44 例 $(0.92 \sim 1.09 \%)$ ，内平 (山口大 ${ }^{6}$ は は同 $39 \sim 48$ 年に年間 $60 \sim 105$ 例 $(1.9 \sim 3.5 \%$ )，41 43 年に 年間 62 99 例 $(2.2 \sim 3.49 \%)$ と報告している。今回の 統部は昭和 $41 \sim 43$ 年飞年間 $30 \sim 49$ 例 $(0.8 \sim 1.4 \%)$ で，他機関の数値之大差はなかつた。年令別では，安田 ら"), 小嶋ら"，溝口2) はいずれも20才代にもつとも多 く, 30 才代とあわせると過半数をしめると報告している が, 今回の統計む同様であつた。

2. 疹型について The Council of Drugs of American Medical Association が副作用登録に用い た分類”（以下 AMA 分類と略）(第 12 表）に記された 32疹型中，13落型か今回観察された。ただ，scarlatiniform eruptions \& morbilliform eruptions をあ わせて斑状丘疹型とし ${ }^{81}$, またerythema multiformelike eruptions, erythema nodosum-like eruptions, erythematous eruptions をあわせて紅斑型と してまとめた。さらに著者は，丘疹・獎液性丘疹型な る疹型を設けたがこれは螿液性斥疹のある症例を集めた ものである。斑状丘翏型が漿液性丘疹に発展するととも あるし，また papulovesicular eruptions (湿疹型) あ当然墏液吽丘疹を示し，乙の両者は丘疹・漿液性丘翏 型に含まれる。Rook ${ }^{\text {9) }}$ は papulovesicular eruptions （湿疹型）の成因を，はじめ外部から感作汃行なわれ， ついで同一または類似薬投与により起こる反応であると 述へ，籏野10) は湿疹型の症状を，経皮惑作部位汇もつと
第 12 表 The Council of Drugs of American Medical Association 0 荟型分類 ${ }^{7}$

o Acne form

Alopecia

Angioedema

Atrophy

Bullous

Depigmented

- Epidermal necrolysis

- Erythema multiforme-like

- Erythema nodosum-like

- Erythematous

- Exfoliated erythroderma

- Fixed

- Hyperpigmented

Ichthyosis-like (dry skin)

Keratosis

Lichen planus-]ike

Lichenoid

Lupus erythematosus-like

- Morbilliform

Monilial

Nail Changes

Necrosis

- Papulovesicular (eczematous)

Pemphigoid

- Photosensitive

Porphyria

Pruritus

Purpuric

- Scarlatiniform

Tumor-like

- Urticarial (including serum-sickness-like anaphylactic)

Vesicular

注）。明は著者統計で観察されたもの

も強い変化があり，全身には散在性に湿疹样変化を生 じ，一見自家感作性皮有炎を彷彿せしめるとのべた。一 方, 北树・川村の教本 ${ }^{11}$ では, 湿疹型に相当する疹型 を「湿疹様ないし小水疮・浮腫性紅皮症型楽疹」と呼 び，感作は経皮的または全身的投与により起こる之述心 ている。こ机ら諸家の記述加らあ考えられるが，経皮感 作部位の症状が顥著でない上, 湿疹型と斑状丘疹型の区 別はつけ難く，著者症例では湿疹型と認められたものは なかつた。最近，利谷 ${ }^{22}$ は湿疹型と这状丘疹型を一括 し「湿绤および林疹型」とした。著者統計であえて丘 疹・嶈液性丘疹型を設けた理由は，漿液性丘疹の有無が 皮疹分布におよに゙す影響をみるためであつた。

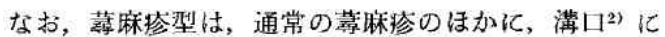

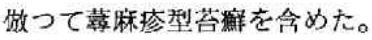

つぎに疹型別頻度であるが，小鸠ら" は固定荟型 40.1 \%, 湿疹型 $5.2 \%$, 光線過敏症型 $3.2 \%$, 紅皮症型 2.7 \%，中毒性表皮塤死症型 $0.2 \%$ ，皮着粘膜眼症候群型 $1.7 \%$ ， その他 $46.3 \%$, 利谷 ${ }^{12)}$ は㢶和 $38 \sim 44$ 年の 西百 
本地区の 11 大学上 1 病院の薬疹 463 例集め, 固定疹 型 156 例 (33.7 \%)，湿疹および麻疹型 147 例 (31.7 \%), 多形紅斑型 51 例 (1196), 䓵麻疹型 44 例 (9.5 \%), 皮周粘膜眼症候群型 22 例 (4.8\%), 紅皮症型 20 例 $(4.3 \%)$, 紫斑型 9 例 $(1.9 \%)$, ジベル著微色粃棣疮 型 7 例 (1.59\%), 中毒性表皮塤死㹥型 2 例 $(0.4 \%)$, 結 節性紅斑型 1 例 $(0.2 \%)$ と報告している。

著者㓍計では, 固定疹型 45.1 名, 斑状丘疹型 25.7 \%, 紅汶型 $11.5 \%$, 质疹・墏液性丘疹型 $8 \%$, 莩麻疹 型 $2.7 \%$ \%であつた（第1表）。

ただし，著者統計では小嶋ら，利公と阔様に，固定疹 型の頻度があつとも高かつた。小嶋らの「湿疹型」之, 利谷の「湿疹および麻疹型」とは同一疹刑の別称で, 著

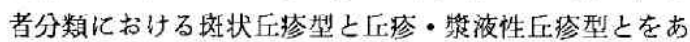
わせたものに相当し，この疹型はそれぞれ統計で第 2 位 の頻度を示したが, 小嶋らのこの型の頻度は著しく低い 点が汒目された。

3. 初診時の皮疹分布について 薬疹は結局は全身皮 萠を侵すが，そこにいたるまでの皮捡分布はさまざまて ある。しかし，そのひろがり方はまつたく不規則ではな くて, 症例によつては一定の傾向が見出される。溝口文 は斑状丘疹型について，全身性のもの，体幹，顾肢を主 とするもの，体幹を主とするもの，顔面を主とするもの など種々の範囲があること，また Rook ${ }^{9)}$ は斑状丘疹型 の皮疹分布をさらにやや具体的に記し，軀幹は通常侵さ れるが，顔はまれであると菦べた。著首の観祭では，皮 疹がいまだ全身に波及していない看例，すなわち皮疹か 2 区分以内にとどまる症例でみると斑状丘疹型は躯幹, 四肢，顔の順に侵されやすく，しかも軀幹，四肢の頻度 は同程度であつたが，顔に睍われることはまれで，この ことはRookの見解とほぼ一致していた。また，丘苳・ 漿液性丘疹型は四肢にもつ上も多く, 糮翰がてれにつ ぎ，顔が侵された例はなかつた。つまり斑状丘疹型と丘 疹・墏波性丘疹型とは，顔の侵されることがまれな点で 類做していた。ところが紅斑型ではやや異なり，四肢の 頻度がもつとも高く，乙れにつぐ軀幹と顔はほぼ同頻度 であつた。

4. 内服試験量について 常用量の $1 / 5 \sim$ 间量をもち いたが，これは初獄時における内服期問の長短, 症状の 㪕重を参考にして決定した。既往における内服期間が長 かつた症例，たとえば第 2 例 (28 日)，また全身症状の 敕かつた症例，たとえば第 3 例では $1 / 2$ 同量を投与し た。一方，既往における内服期間が短かつた症例，た之 えば第 4 例 (2几)，第 1 例（1龱），また皮疹が急速に 全身に拡大し，かつ強い全身怔状をともなつた症例，た
とえば第 1 例および第 4 例では $1 / 4 \sim 1 / 5$ 量を投与した。 第 5 例は発症までの内服期間が短く（1日),かつ急速に 皮疹が掋大し，高熱をとむなつていたのに内服試験で问 量老投与したのは過量であり，また第6 例における $1 / 2$ 量む過量であつた。乙の第 5 ，第 6 の2例を除いた残り 4 例では, 内眠試呀後しばらく観察したが, 発症しない のでさらに追投与し，その観察期間は第 1 例で 1 時 間, 第 2 例で 6 時間, 第 3 例で 30 時間, 第 4 例で 24 時 間のごとくさまざまであつたが，第 1 例の 1 時間は明ら かに短かすぎた。ちなみに追加投占量は，第 1 ，第 2 例 では初回量と同量, 第 3 , 第 4 例では初间量の倍量であ つた。

要するに, これら6 例のうち, 此較的適划な内服試験 が行なわれたと思われるのは，第 3 ，第 4 の2例で，そ れぞれ初回に $1 / 2$ 量，1/5量を投与したが，30時間，24 時間後に反応がみられなかつたので，初回の倍量を追加 投与し，それぞれ 14 時間，1時間後に比較的㹩い発症 をみたのである。

内服試験が隄性を咞した 薬疹事例を摘録してみると (第 13 表)，常用 1 回量の 2/5 1/2 量のすのが多い。乙 れは通常，原則量として唱えられている $1 / 10$ 量 $^{6) 14) 17 ~}$ 18)よりやや多い值である。著者例では没疹消退後 2 日 ないし２速を経て内服試験を行なつたが，施行牌期と内 服試䮖量上の関係も勘案する必要があろう。さらに，迎 加内服をする場合, 束ら ${ }^{18)}$ のいうように24 時間後に行 なうべきとも思うが，著者は 1 例を除いて 24 時問以内 に追加投与を行なつた。追川投与の時期と量について は, 薬剂の血中あるいは臟器内濃度, 排泄速度, 個体の 過敏性などが関速してくるであろう。

5. 内服試験時の皮疹分布 内服武験を行なつた症例 で, 初㟝時と内服試験時の皮疹分布を比較した（第 1 6 図)。

1）皮疹分布の異同について：初診時に皮疹が全身に およんでいたものを除き第 3 ，第 4 ，第 6 の3 例で観祭 した。第 3 例 (phenobarbital, Er疹・獎液性丘疼型) では内服試験時には前腕のみ，初检時にはそのほかに下 腿, 足背にあ汥琴がみられ，また第 4 例 (sulfisomezole, 紅斑型) では，内服試験時には手背のみに，初診時には そのほかに顔, 腹, 前腕, 下腿にも皮瘆がみられ, これ ら 2 症例では, 内服試験時の皮疹分布は初診時のそれの 一部にすぎなかつた。したがつて，発症のたびに皮䖉分 布はさして動いていないと考えてよい。

上ころが第6 例 (sulfamonometoxine，中毒性表皮 壊死症型）では禹幹，阢肢は初猃時にも内服試蛤時にも 侵されていたが，指趾を除く四肢は初馀時のみに，顔面 


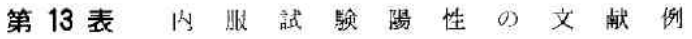

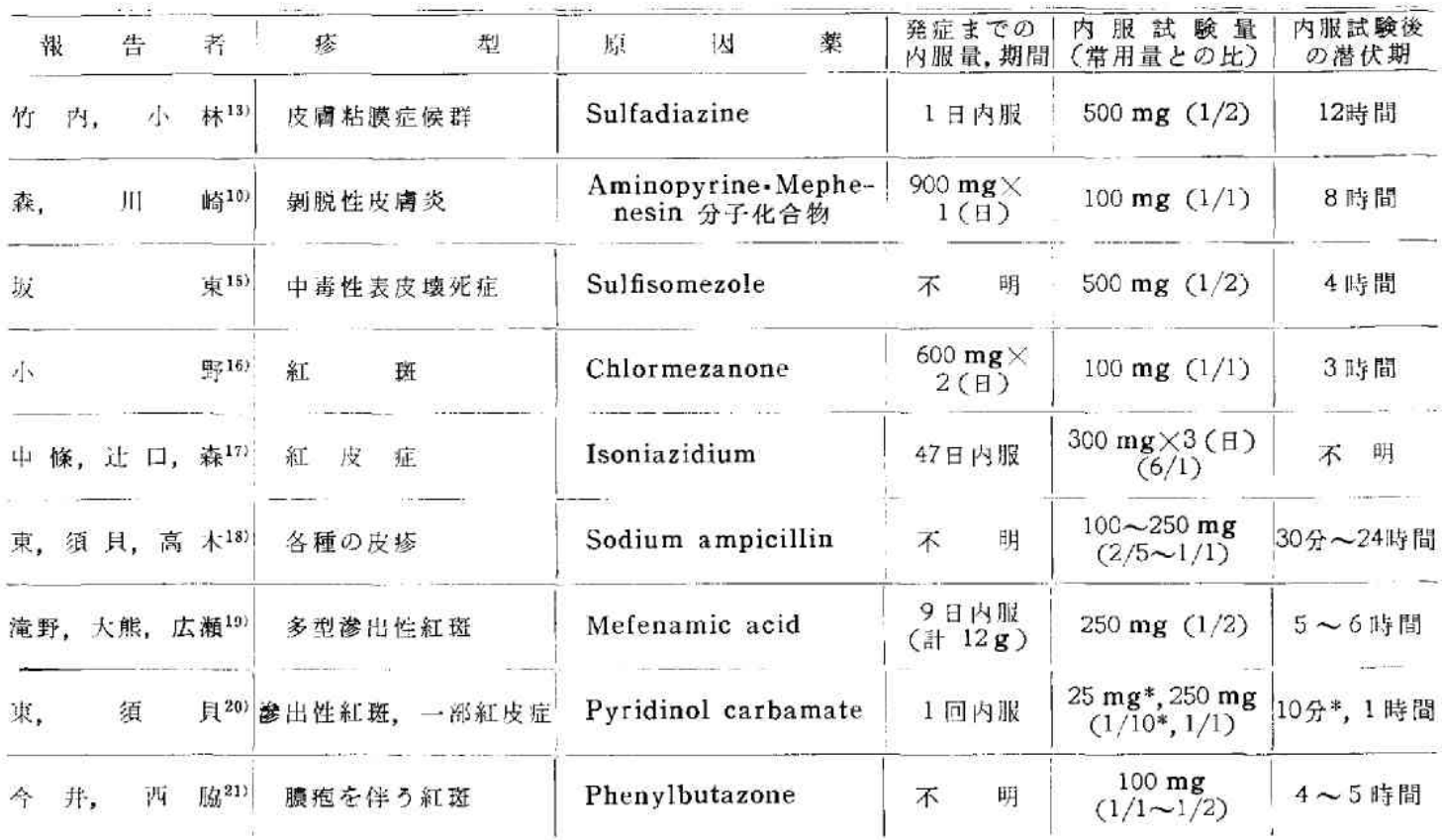

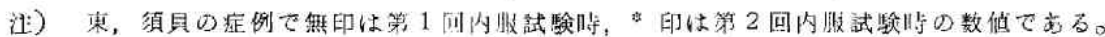
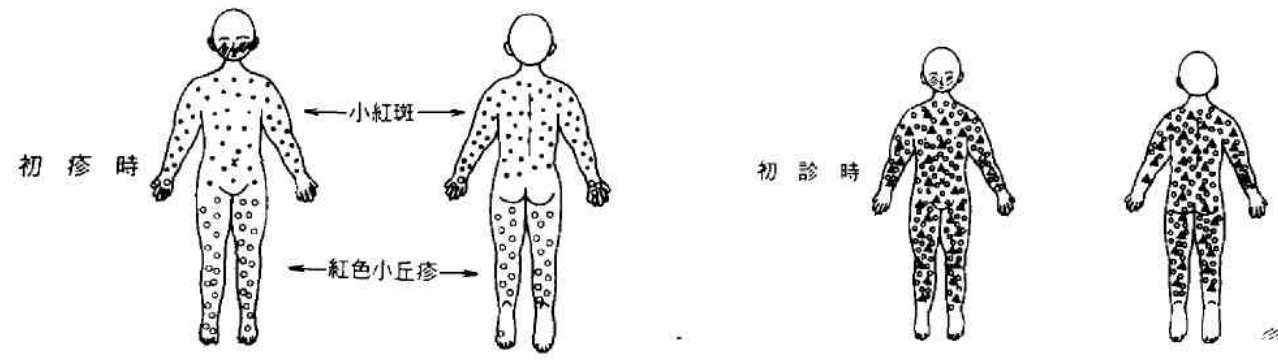

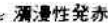

- 小紅斑

- 紅色小丘厚

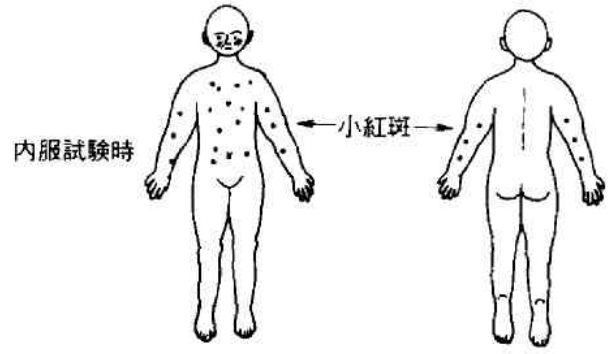

第1図第 1 例 Sulfisomezole $几$ 上る斑状丘疹型

は内服試験時のみに侵されていた。つまりとの例では， 早期に強く侵される部位（軀幹，指趾）は其通していた が，続いて侵される部佁は発症のたびにいくつかの变動

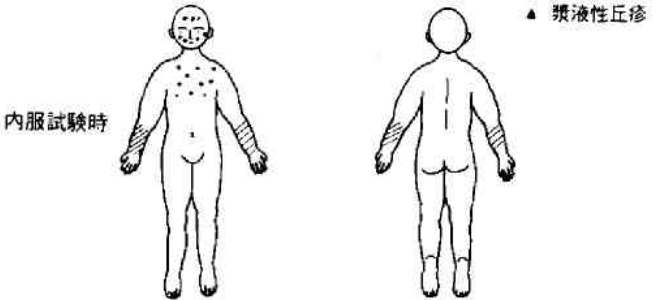

第2図第2 例 Sodium oxacillin に上る 斤疹, 奬液性斥疹烈

を示したととがわかつた。

2) 十肢と下肢とにおける皮疹出現の時問的関係：上 肢と卜肢に同時に皮疹が現われた第 5 ,第 6 の2 例は, こ の問題の対象となりえなかつたが，第1 (sulfisomezole, 玟状兵洿型), 第 2 (sodium oxacillin, 兵落・ 

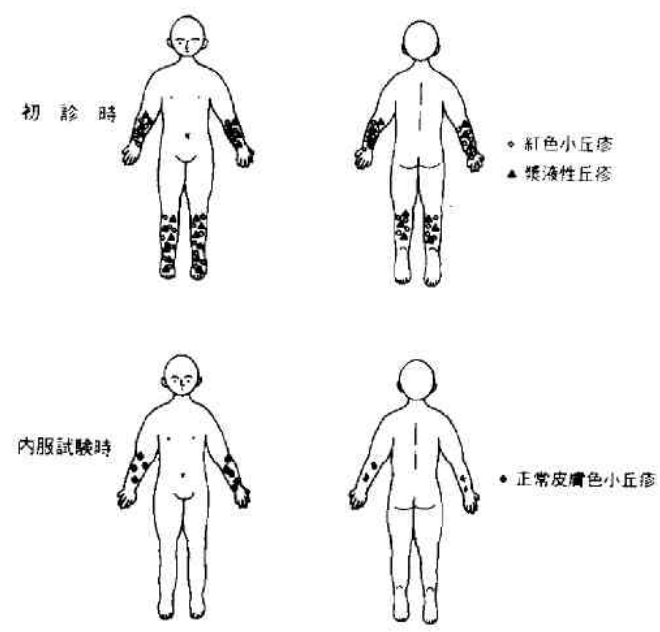

第3図第3 例 Phenobarbital k上る

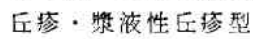
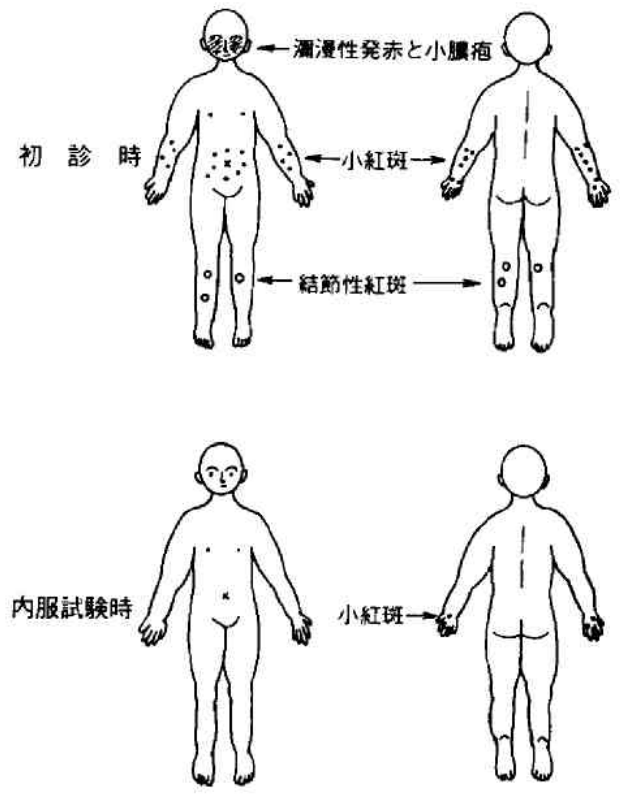

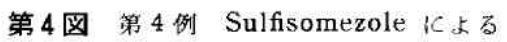
社斑型

㢡液性丘疹型)，第3，第404例では，上肢と卜肢之 において皮苳出現の時間的相違がみられた。すなわちて れら 4 例では, 初診時には上肢, 下肢ともに侵されてい たが，内服試験時にはすへて上肢のみが侵され，ド肢は 侵されていなかつた。したがつててれらの例に関する限 り，下肢は上肢にくらべ皮疹出現時間が迩れると考えて よい。

3）四肢之軀幹，顔面における皮捡出晛の時間的関係
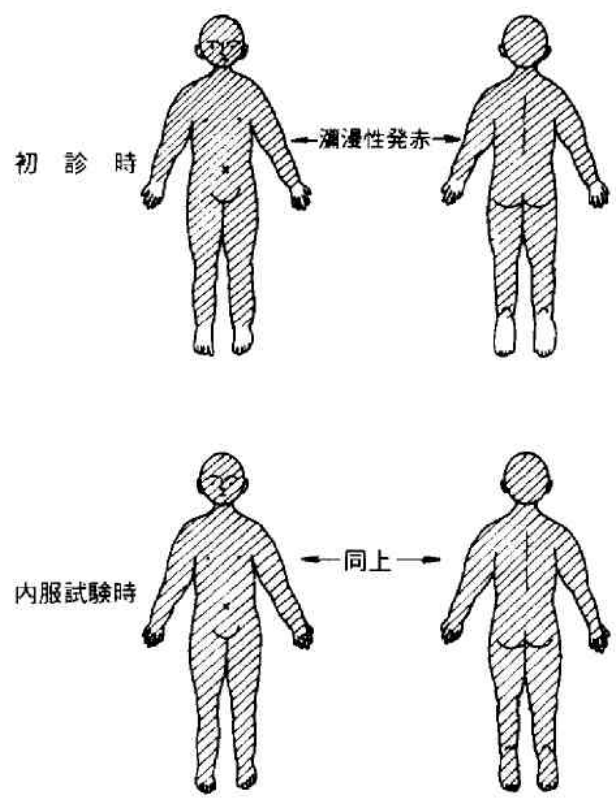

第 5 図第 5 例 Carbamazepine $に 上$ る絓度症型
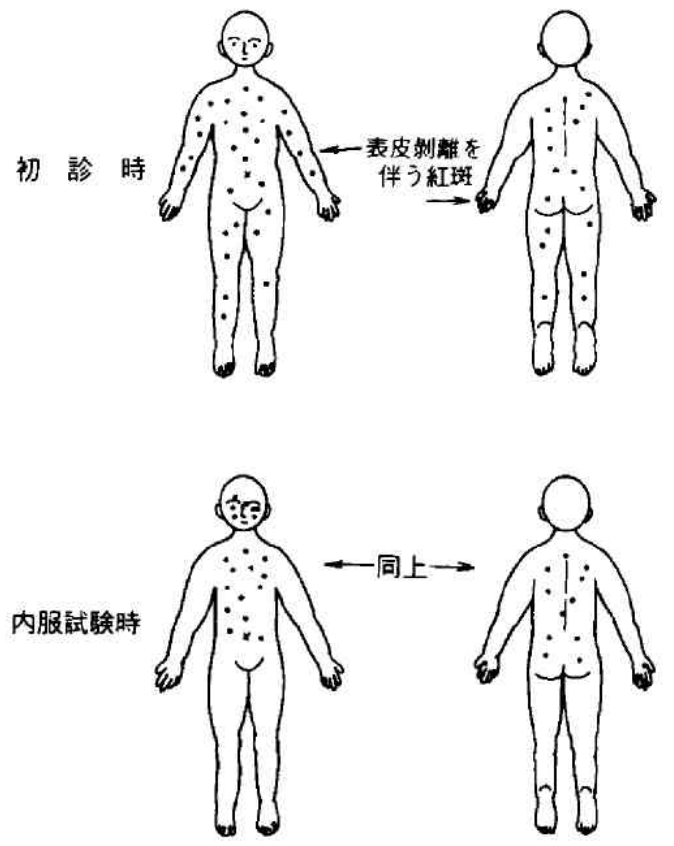

第6図 第 6 例 Susfamonometoxine $に$ 去る中毒性表皮壊死班型

: 第 3 ，第 4 の 2 例がこの問題の対象上なつた。すなお 5第 3 例 (丘疹・䠌液性斥疹型) では初診時, 内服試験 時と屯に皮疹は四肢のみに見われ，第 4 例 (紅斑刑) で 
は初埥時には全身に，内服試験時には指背，手背のみに

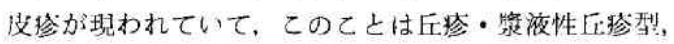
紅斑型の皮疹分布の一般的棁式，つまり阳肢に皮疹が牛: じやすい事実に一致していた。

ところで第6 例では, 初新時と内服試験時 とで皮疹 発生部位がいれかわり,やや複雑枚関係を示し, この問 題解決にはあまり参考にならず，また第 1 , 第 2 , 第 5

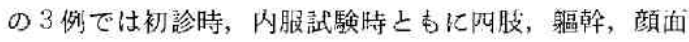
が同時に侵されていたのでこの閣題検討の対象にはな らなかつた。な旅 5 例 (carbamazepine, 紅发㤱) では掌瞊が最後に侵されたのが注目された。

6. 内服試験時の血液像 白血球增多は 3 例（第之, 4，5例）飞みられ，第2 2 例 (sodium oxacillin， 瓜 翏・漿液性丘疹型）ては内服試験開始後, 皮疹が出兒し た 5 時間時の白血球数 $10700 / \mathrm{cmm}$ で, 分葉核好中球が $74 \%$ \%しめ，第 4 例（sulfisomezole，紤斑型）では文 将が出見した同じく 1 時間㭙の白血球数法 $18200 / \mathrm{cmm}$, 分葉核好中球か $78 \%$ を占加，第 5 例 (carbamazepine, 紅皮症型)では同じく 4 時間時, すなわち皮疹出現から 2 時間後の白血球数は $6800 / \mathrm{cmm}, 24$ 時間㭙には 12200 $/ \mathrm{cmm}$ 之著增し, 好票球が $45 \%$ \%し, この例におい ては，発症直後より副腎皮質木ルモンを投'jしたにもか がらず好酸球增多がみられた。

白血球减少は 3 例にみられ，第 1 例 (sulfisomezole, 斑状斥疹型)，第6 例 (sulfamonometoxine, 中毒性

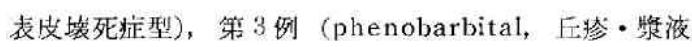
性丘疹型) がそれで、第1例にはリンバ球減少 (1496) がみられた。

買型リンパ球は第3，第5例にそれぞれ $2.5 \%$ ，1\% にみられ，上屯に発聇直後にはなく24 時間後にみられ た。好壒基球は第 1 ，第 3 例飞0.5\%，1\% みられた。 恮球娍少がみられたのは第 2 , 第 6 例で $5 \sim 9.7 \times 10^{4} /$ $\mathrm{cmm}$ と軽度〜中等度減少值を示し, 他 1 例（第 3 例) 法止常值を示した。

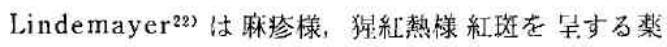
骖で, 骨䯣が侵襲され, 白血球減少, 栓球减少, 無顆粒 球症がしばしば胃われ，さらにその二次度応としてロ
搵梂增多を惹起するとのべた。大久保 ${ }^{2324)}$ (薬物過的 柾に内服武験老行ない, 多数例で白血球減少, 上くに好 中球减少が，また少数例では白血球增多がみられたこ 上，またPAS 過敏症の 1 例に内服試験を行ない，2 時 間後に白血球数 $4000 / \mathrm{cmm}$ 上減少，8時間後には逆沉 $17700 / \mathrm{cmm}$ に增加したととを報告し, Lindemayer の唱えるとてろと一致した所胃をみとめた。著者例では 白血球增多が 3 例にみられたが，いずれも皮疼発現時に 算定したすのであつて，より早期に検查すれば白血球減 少がみられたのかもしれない。

7. 内服試験施行例のその他の所見 粘膜检は 6 例中 2 例飞みられ、リンバ節腫脹は 4 例（すべて両側顒部，

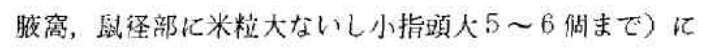
みられた。

発熱上皮疹出現の時間的関係索 6 例の初沴時上内服試 検時につき檢领し，つぎの 5 群に少けた（第14表）。すな わち (1)屾者が同時に垷われた群（间時），(2)皮翏が発熱 に先行した群（波疹先行），(3)発熱が皮疹に先行した群 (発熱先行)，(4)皮疹のみで発熱をともなわない群（伎 疹のみ), (5)発熱のみで皮疹をとむなわない群（発熱の み）である。「问時」は 12 回中 5 回，「皮翏先行」は 4 问,「発熱先行」は 1 川, 「皮疹のみ」2[四であつた。た

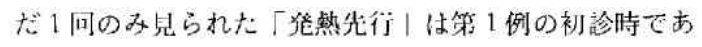
るが，乙の例む内服試䀫時には「皮答先行」を小した。 「発熱のみ」の型は今国経験されなかつたが，行植 ${ }^{25}$ は 1 力月以上総いた弛張熱が cephalosporin の中止によ り解熱した例在報告している。尿は6 例中2例だけし か検查しなかつたが 1 例は正常, 他の1例（第 4 例, sulfisomezole，紅斑型）は䖝白(一)であつたが矿

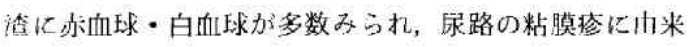
するわのと考えられた。时機能 (GOT, TTT, ZST, LDH) は3 例で検查したが, 第 1 例 (sulfisomezole,

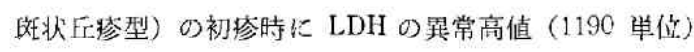
をみとめたほかはすべて正常であつた。

血茂は 3 例（第 4, 5, 6 例）で検查し, 第 4 例の初彰 洔, 第 5 例の内服試䮖時, 第 6 例の初喰時之内服試験時 に灾连していた。血压は発症時に 4 例で測定し，うち 3

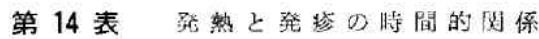

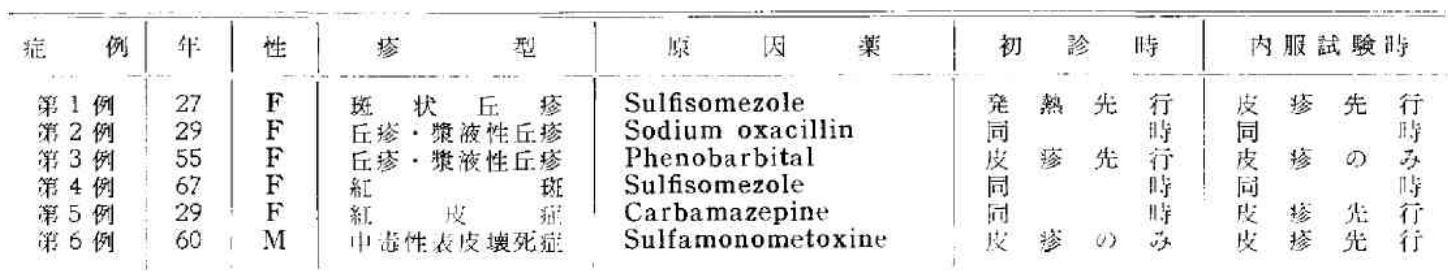


例は正常，残る 1 例 (第 1 例) は内服試験後 5 時間時に 98/60，11 時間時に $82 / 0$ のごとく低下を示した。尿素 空素は第 4 例の初診時之内服試験時にやや高值 (25 mg/ dl)を示した。

斯布试験は施行した5例中 1 例（第！例）のみに陽性 であつた。没内片応は1例（第 2 例, sodium oxacillin,

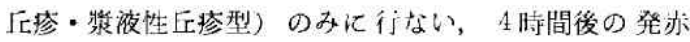
に正常人之有意差を認めた。紅玟面上に膿泡が多発す る特異な症状が第 4 例で観察された。これは sulfisomezole により上肢，軀幹に滲出性紅斑，下肢に結節性 㱍斑が現われ，顔面の縕斑面上江無菌性膿䳐が集簇性に みられた症例である。今井ら211は麻疹様絸斑面上に膿 疱が多発した phenylbutazone 疹を初めて報告した。 膿疮, 動脈血からの細菌培養は陰性で, 木梢白血球数は $22900 / \mathrm{cmm}$, そのうち嘲状核奵中球が 33.86 であり, 以 服および貼布武験で膿狍をともなつた皮疹を再垷しえた という。Macmillan ${ }^{26)}$ む沈発した紅斑酒 I:に膿疮が多 発した 4 例を generalized pustular drug rash と題 して報告し，その原因薬は piperazine phosphate， pyrimethamine, fursemide などで膿疮からの細菌培 養は 4 例中 3 例で陰性, 白血球增多を 3 例中 2 例に認め た。著者の第 4 例も，紅斑面上に膿狍が多発した踟床 像, 白血球增多, 膿疮からの練菌培養が陰性であること などの諸点で今井例，Macmillan 例の一部之共通して いた。

\section{V. ま め}

1) 昭和 $41 \sim 43$ 年の東大分院皮俤科における薬疹例 は年間 30〜 49 例，計 113 例で，外来患者総数の $0.8 \sim$ 1.196 , 平均 $1.08 \%$ にあたり，当時における他医療機関 の統計と大差はなかつた。

2 ) 年令別では 20 才代にもつ上む多く (31 例)，30 才代がこれにつき(28例)，両者をあわせると過半数を しめていた。

3) American Medical Association がもちいた分 類を勘案し、著者例を 13 の疹型に分けたが,それによ ると固定疹型がもつとも多く (45.18)，以下斑状 丘疹 型 $(25.7$ \%)，紅斑型 $(11.5 \%)$ ， 丘疹・漿液性丘疹型 $(8 \%)$, 臀麻疹型 $(2.7 \%)$, 紅皮症型 $(0.9 \%)$, 座瘡型 $(0.9 \%)$, 中毒性表皮壊死症型 $(0.9 \%)$, 光線 過敏症型 (0.9\%) の順であつた。

4） 113 例中，原无楽を確認しえたものは 31 例で， そのうち 10 例は内服または注射または貼布により, 残 り 21 例は問豂によつで推定した向のである。 原因薬としては抗生物質 (12 例)，サルファ剂 (8 例)
が多く、鎮痛解熱楽 (2例)，ての他 (9例) で, これ らを 紐別すると chloramphenicol ( 5 例), sulfisomezole ( 3 例), sulfamonometoxine ( 2 例), carbamazepine ( 2 例)，企（2例）が扰むなのです t。

5) 各疹型における皮疹分布は，斑状斥疹型と斤疹・

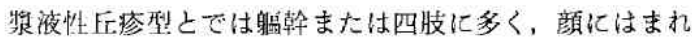
であつたが，絟坟型は四肢に多く，軀幹已顔が问頻度 でこれについでいた。

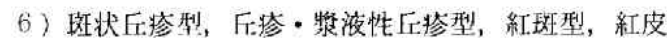
症型，中㶳性表皮壊死症型では内服武験量は常用量の 1/5 程度から始め, 反応がなければ迎加する方法が適切 と思われた。

7)四肢に打ける支疹は，1:肢に早期に，下肢に遅れ て出現する傾问がみら机た。

8) 初猃特亡内服試験時における皮疹分布の異同を, 全身例は別として, 3 例 (phenobarbital, sulfisomezole, sulfamonometoxine 各 1 例) で娭討したか， 早期に強く侵される部位は两者間で相異はなかつた。

9) 内服武験時の血洨像では, 白血球増多が 3 例, 白 血球减少が 3 例みられ, 白血球増多例では分葉核好中球 増加による場合と，好酸球增加による場合とがあり，さ らに栓球は検査した 2 例ともに減少していた。

10）紅玫面上に膿狍の多発したまれな suifisomeznie 捡1例について詳述した。

（㭻を終えるに市たり微校閲を戴いた京都府立乲人名誉 教授岩下健三先生に深く惑澌いたします。東人分院在聵

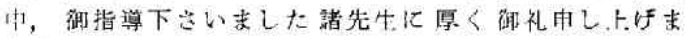
के )

\section{文献}

1）样口謙太郎・他：皮と泌，28：29，1966.

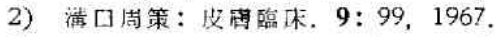

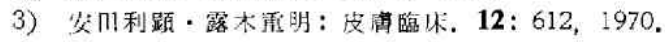

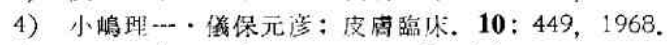

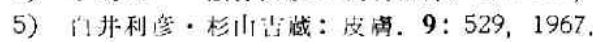

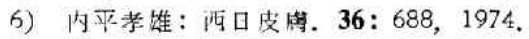

7) Fitzpatrick, T. B. et al.: Dermatology in General Medicine, McGraw-Hill Book Co.. New York etc., 1971, p. 1301.

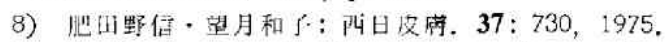

9) Rook, A.: Textbook of Dermatology, ed. by A. Rook et al., Blackwell Scientific Publications, Oxford \& Edinburgh, 1968, p. 370 ,

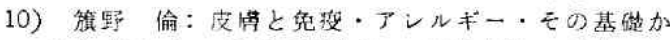

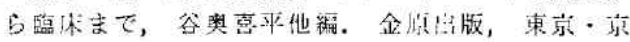
都, 1974, p.237.

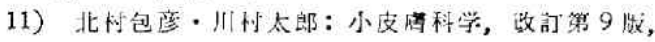


金源出版，東京・京都，1973，p. 156.

12) 利谷昭治：臨林と研究. 48: 1166, 1971.

13）竹内 幐.小林健正：皮府臨床, 2: 632, 1960 ,

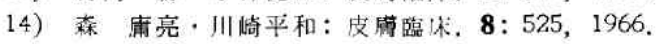

15）坂東嫩葉：皮苗郘惊，9:978，1967.

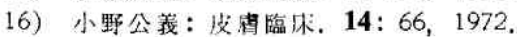

17）中條知孝・他：皮洁臨休. 16：3，1974。

18) 東 順子. 他：隐度. 28: 389, 1974.

19) 滰野長平. 他：臨皮, 28: 467, 1974 .

20) 束 順了. 須具暂郎：隐皮。 27: 863, 1973.

21）今井清治.他：皮阅臨休．10：441，1968.

22) Lindemayer, W. und Partsch, W.: Wien.
Klin. Wschr. 82: 473, 1970.

23) 大久保滉：日血会誌. 26:267, 1963.

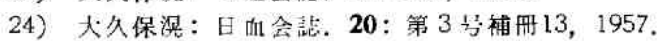

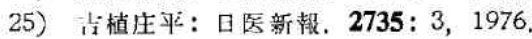

26) Macmillan, A, L. : Dermatologica. 146: $285,1973$.

$$
\text { (昭和53年 } 5 \text { 月 } 29 \text { 日 受讨) }
$$

\begin{tabular}{|c|c|}
\hline 別剧站求先： $\overline{\boldsymbol{T}} 150$ & 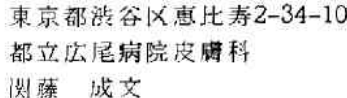 \\
\hline
\end{tabular}

\section{新 刊紹 介}

\section{Progress in Allergy, Vol. 25}

P. Kallos, B. H. Waksman \& A. L. de Weck 著 $245 \times 175$ mm, 242 ページ, S. Karger, 1978, 15,840円

免度学あるいは臨床アレルギー学に関する最新のト ピックスについて, 下記の 5 編の総説をのせている。

1) 定量的な免疫電条泳動法とアレルゲン分析：電 父泳動とゲル内沈降反応を組み合わせた定最法の紹介 と，それをアレルケ゚ン分析に応用する方怯。

2) Muramyl dipeptide の活性: 人士命成したア ジュパント物質と天然アジュバントの比較。
3) Lymphokine の精製と性状：リンパ球加ら放 出される細胞性免疫の后性物質について。

4) 腫瘄免疫のメカニズム: 腫瘍の成長抑制と抗体 の関係，また免疫以外のメカニズムによる抑制因子に эい

5) 癩の免辿：癩の条病型に求ける免疫異常（次 損）の状態や免疫療法について。 